\title{
Modulation of ion transport across rat distal colon by cysteine
}

\section{Ervice Pouokam and Martin Diener*}

Institute for Veterinary Physiology and Biochemistry, University Giessen, Giessen, Germany

Edited by:

Wolfgang G. Clauss,

Justus-Liebig-University Giessen,

Germany

Reviewed by:

Beate Illek, Children's Hospital and

Research Center Oakland, USA

Salah Amasheh, Charité

Universitätsmedizin Berlin, Germany

Yoshinori Marunaka, Kyoto Prefectural

University of Medicine, Japan

${ }^{*}$ Correspondence:

Martin Diener, Institut für

Veterinär-Physiologie und-Biochemie,

Justus-Liebig-Universität Gießen,

Frankfurter Str. 100, D-35392 Gießen,

Germany.

e-mail:martin.diener@

vetmed.uni-giessen.de
The aim of this study was to identify the actions of stimulation of endogenous production of $\mathrm{H}_{2} \mathrm{~S}$ by cysteine, the substrate for the two $\mathrm{H}_{2} \mathrm{~S}$-producing enzymes, cystathionine- $\beta$ synthase and cystathionine- $\gamma$-lyase, on ion transport across rat distal colon. Changes in short-circuit current (Isc) induced by cysteine were measured in Ussing chambers. Free cysteine caused a concentration-dependent, transient fall in Isc, which was sensitive to amino-oxyacetate and $\beta$-cyano-L-alanine, i.e., inhibitors of $\mathrm{H}_{2} \mathrm{~S}$-producing enzymes. In contrast, $\mathrm{Na}$ cysteinate evoked a biphasic change in Isc, i.e., an initial fall followed by a secondary increase, which was also reduced by these enzyme inhibitors. All responses were dependent on the presence of $\mathrm{Cl}^{-}$and inhibited by bumetanide, suggesting that free cysteine induces an inhibition of transcellular $\mathrm{Cl}^{-}$secretion, whereas $\mathrm{Na}$ cysteinate - after a transient inhibitory phase - activates anion secretion. The assumed reason for this discrepancy is a fall in the cytosolic $\mathrm{pH}$ induced by free cysteine, but not by Na cysteinate, as observed in isolated colonic crypts loaded with the pH-sensitive dye, BCECF. Intracellular acidification is known to inhibit epithelial $\mathrm{K}^{+}$channels. Indeed, after preinhibition of basolateral $\mathrm{K}^{+}$channels with tetrapentylammonium or $\mathrm{Ba}^{2+}$, the negative Isc induced by free cysteine was reduced significantly. In consequence, stimulation of endogenous $\mathrm{H}_{2} \mathrm{~S}$ production by $\mathrm{Na}$ cysteinate causes, after a short inhibitory response, a delayed activation of anion secretion, which is missing in the case of free cysteine, probably due to the cytosolic acidification. In contrast, diallyl trisulfide, which is intracellularly converted to $\mathrm{H}_{2} \mathrm{~S}$, only evoked a monophasic increase in Isc without the initial fall observed with $\mathrm{Na}$ cysteinate. Consequently, time course and amount of produced $\mathrm{H}_{2} \mathrm{~S}$ seem to strongly influence the functional response of the colonic epithelium evoked by this gasotransmitter.

Keywords: $\mathrm{Cl}^{-}$secretion, cysteine, cytosolic $\mathrm{pH}$, electrolyte transport, $\mathrm{H}_{2} \mathrm{~S}$, rat colon

\section{INTRODUCTION}

Colonic ion transport is not only controlled by classical neurotransmitters or hormones (for review see Binder and Sandle, 1994), but is also influenced by gasotransmitters such as nitric oxide (Toda and Herman, 2005), carbon monoxide (Steidle and Diener, 2011), or hydrogen sulfide (Schicho et al., 2006; Hennig and Diener, 2009). The latter gas is produced from the amino acid cysteine via the enzymes cystathionine- $\beta$-synthase and cystathionine$\gamma$-lyase (Wang, 2002; Martin et al., 2010). Both enzymes are found within enteric ganglia of guinea-pig and human colon (Schicho et al., 2006) as well as in smooth muscle layers and the epithelium of rat colon (Hennig and Diener, 2009). Plasma levels of $\mathrm{H}_{2} \mathrm{~S}$ are reported in the range of $50-160 \mu \mathrm{mol} \cdot \mathrm{l}^{-1}$ (Zhao et al., 2003). The local concentration within the intestinal wall is unknown, but the production rate of $\mathrm{H}_{2} \mathrm{~S}$ has been measured for rat ileum to be in the range of $12 \mathrm{nmol} \cdot \mathrm{min}^{-1} \cdot \mathrm{g}^{-1}$ tissue (Zhao et al., 2003). Furthermore, there is an upregulation of $\mathrm{H}_{2} \mathrm{~S}$ production during experimental colitis in rats (Wallace et al., 2009), so that rat colon is an interesting model to investigate the modulation of ion transport by this gasotransmitter.

Hydrogen sulfide, which can be released from a donor molecule such as NaHS (Lee et al., 2006), evokes a $\mathrm{Cl}^{-}$secretion in guinea-pig and human colon. In these tissues, the primary action site of this $\mathrm{H}_{2} \mathrm{~S}$ donor are enteric neurons, where $\mathrm{H}_{2} \mathrm{~S}$ is thought to act at capsaicin-sensitive cation channels of the type transient receptor potential vanilloid receptor 1 (TRPV1; Schicho et al., 2006). The consequence is a release of substance $P$ and an activation of secretomotor submucosal neurons, which finally induce epithelial anion secretion (Krueger et al., 2010). This is supported by the observation that NaHS does not evoke anion secretion in the human colonic cell line, T84 (Schicho et al., 2006). Another mechanism of action of NaHS was observed in rat colon. In this tissue, NaHS evokes a triphasic change in Isc, which is a measure of net ion movement across the epithelium. An initial increase in Isc (mediated by $\mathrm{Cl}^{-}$secretion) was followed by a transient fall (assumed to represent a transient $\mathrm{K}^{+}$secretion), before the Isc finally rose again to a long-lasting $\mathrm{Cl}^{-}$secretory response. Partial resistance against the neurotoxin, tetrodotoxin, and inhibition by glibenclamide, which acts as blocker of ATP-sensitive $\mathrm{K}^{+}$channels (Cook and Quast, 1990), as well as tetrapentylammonium, known as inhibitor of $\mathrm{Ca}^{2+}$-dependent $\mathrm{K}^{+}$channels (Maguire et al., 1999), indicated an action at epithelial $\mathrm{K}^{+}$channels (Hennig and Diener, 2009). Direct epithelial actions of $\mathrm{H}_{2} \mathrm{~S}$ released from NaHS were observed in experiments at isolated colonic crypts loaded with 
the $\mathrm{Ca}^{2+}$-sensitive fluorescent dye, fura-2, where NaHS evoked a biphasic change in the cytosolic $\mathrm{Ca}^{2+}$ concentration $\left(\left[\mathrm{Ca}^{2+}\right]_{i}\right)$, i.e., an initial decrease followed by a secondary increase (Pouokam and Diener, 2011). Consequently, there seem to be pronounced species differences in the mechanism of action of $\mathrm{NaHS}$.

In the literature, there is a controversy about beneficial and/or adverse effects of $\mathrm{H}_{2} \mathrm{~S}$ on intestinal functions. The above mentioned in vitro studies, although differing in the presumed mechanisms of action, indicate a prosecretory action of this putative gasotransmitter, which - in vivo - would aggravate gastrointestinal symptoms such as diarrhoe, e.g., during inflammatory bowel disease. Indeed, $\mathrm{H}_{2} \mathrm{~S}$ exerts proinflammatory actions in a mouse model of acute pancreatitis (Tamizhselvi et al., 2007). Further negative actions of $\mathrm{H}_{2} \mathrm{~S}$ on gastrointestinal integrity have been deduced from the observation that inhibition of $\mathrm{H}_{2} \mathrm{~S}$ synthesis by propargylglycine protects rats from ethanol-induced gastritis (Chávez-Piña et al., 2010). In contrast, other experimental evidence clearly demonstrates beneficial effects of this gasotransmitter. Exogenous $\mathrm{H}_{2} \mathrm{~S}$ exerts an antiinflammatory and antinociceptive action during synovitis in rats (Ekundi-Valentim et al., 2010). The $\mathrm{H}_{2} \mathrm{~S}$-releasing derivative of mesalamine, ATB429 , is highly effective as therapeutic in a model of murine colitis (Fiorucci et al., 2007). Further protective actions of hydrogen sulfide are observed in the heart, where this gasotransmitter protects against ischemia/reperfusion damage (Ji et al., 2008). In contrast to the model of ethanol-induced gastritis (Chávez-Piña et al., 2010), where the beneficial effect of blockade of $\mathrm{H}_{2} \mathrm{~S}$ synthesis suggests proinflammatory actions of $\mathrm{H}_{2} \mathrm{~S}$, the gastric damage caused by inhibitors of cyclooxygenases has been found to be reduced when using a cyclooxygenase inhibitor which simultaneously releases $\mathrm{H}_{2} \mathrm{~S}$ (Wallace et al., 2010). As in some studies both inhibition of $\mathrm{H}_{2} \mathrm{~S}$ synthesis as well as its stimulation by cysteine, the precursor for $\mathrm{H}_{2} \mathrm{~S}$ production, exert a similar response (Chávez-Piña et al., 2010), one reason for this discrepancy in the literature might be that the effect evoked by $\mathrm{H}_{2} \mathrm{~S}$ may differ in situations, where endogenous enzymes probably produce relative low concentrations of this gasotransmitter, and situations, in which exogenous donor molecules might release higher concentrations of $\mathrm{H}_{2} \mathrm{~S}$.

Consequently, in the present study we investigated changes in ion transport across rat colon, in which we had previously characterized the effect of the exogenous $\mathrm{H}_{2} \mathrm{~S}$ donor, NaHS (Hennig and Diener, 2009; Pouokam and Diener, 2011), induced by cysteine as precursor of endogenous $\mathrm{H}_{2} \mathrm{~S}$ formation within the tissue. Ussing chamber experiments and experiments with the $\mathrm{pH}$-sensitive dye, BCECF, were used in order to identify the mechanisms involved.

\section{MATERIALS AND METHODS SOLUTIONS}

The standard solution for the Ussing chamber experiments was a buffer solution containing (mmol. $\left.\mathrm{l}^{-1}\right)$ : $\mathrm{NaCl} 107, \mathrm{KCl} 4.5$, $\mathrm{NaHCO}_{3} 25, \mathrm{Na}_{2} \mathrm{HPO}_{4}$ 1.8, $\mathrm{NaH}_{2} \mathrm{PO}_{4} \quad 0.2, \mathrm{CaCl}_{2} 1.25, \mathrm{MgSO}_{4} \cdot 1$ and glucose 12 . The solution was gassed with carbogen $\left(5 \% \mathrm{CO}_{2}\right.$ in $95 \% \mathrm{O}_{2}$, vol.vol ${ }^{-1}$ ); $\mathrm{pH}$ was 7.4 . For the $\mathrm{Cl}^{-}$-free buffer, $\mathrm{NaCl}$ and $\mathrm{KCl}$ were equimolarly substituted by $\mathrm{Na}$ gluconate and $\mathrm{K}$ gluconate, respectively.
For the experiments carried out with isolated crypts, the following buffers were used. The EDTA (ethylenediamino-tetraacetic acid) solution for the isolation contained $\left(\mathrm{mmol}^{-1} \mathrm{l}^{-1}\right)$ : $\mathrm{NaCl} 107$, $\mathrm{KCl} 4.5, \mathrm{NaHCO}_{3} 25, \mathrm{Na}_{2} \mathrm{HPO}_{4} 1.8, \mathrm{NaH}_{2} \mathrm{PO}_{4}$ 0.2, glucose 12.2, EDTA 10 and $1 \mathrm{~g} \cdot \mathrm{l}^{-1}$ bovine serum albumin (BSA). It was gassed with carbogen; $\mathrm{pH}$ was adjusted by tris-base (tris(hydroxymethyl)aminomethane) to 7.4. The isolated crypts were stored in a high potassium Tyrode solution consisting of $\left(\mathrm{mmol} \cdot \mathrm{l}^{-1}\right)$ : K gluconate 100, KCl 30, HEPES ( $N$-(2-hydroxyethyl)piperazine- $N^{\prime}-2$ ethanesulfonic acid) $10, \mathrm{NaCl} 20, \mathrm{MgCl}_{2} 1, \mathrm{CaCl}_{2} 1.25$, glucose 12.2 , sodium pyruvate 5 , and $1 \mathrm{~g} \cdot 1^{-1} \mathrm{BSA} ; \mathrm{pH}$ was 7.4 . For superfusion of the isolated crypts during the imaging experiments, the following buffer was used (in mmol. $\mathrm{l}^{-1}$ ): $\mathrm{NaCl} 140, \mathrm{KCl} 5.4, \mathrm{CaCl}_{2}$ 1.25, $\mathrm{MgSO}_{4}$ 1, HEPES 10, glucose 12.2. $\mathrm{pH}$ was 7.4.

\section{TISSUE PREPARATION AND CRYPT ISOLATION}

Wistar rats of both sexes were used with a weight of 180-240 g. The animals had free access to water and a standard rat diet until the day of the experiment. Animals were killed by a blow on the head followed by exsanguination (approved by Regierungspräsidium Gießen, Gießen, Germany). The serosa and muscularis propria were stripped away to obtain a mucosa-submucosa preparation of the distal colon. The distal colon was distinguished from the proximal colon by the absence of palm leaf-like striae (Lindström et al., 1979). Briefly, the colon was placed on a small plastic rod with a diameter of $5 \mathrm{~mm}$. A circular incision was made near the anal end with a blunt scalpel and the serosa together with the lamina propria were gently removed in a proximal direction. Two segments of the distal colon of each rat were prepared. In general, one tissue served to measure the control response evoked by cysteine and the other to measure the response in the presence of a putative inhibitor (see below). There was no obvious segment dependence in the Isc evoked by cysteine between the early and the late distal colon (data not shown).

For the isolation of intact crypts, the mucosa-submucosa was fixed on a plastic holder with tissue adhesive and transferred for about 7 min to the EDTA solution. The mucosa was vibrated once for $30 \mathrm{~s}$ in order to obtain crypts. They were collected in a high- $\mathrm{K}^{+}$ gluconate Tyrode buffer (Böhme et al., 1991).

\section{SHORT-CIRCUIT CURRENT MEASUREMENT}

The mucosa-submucosa preparation was fixed in a modified Ussing chamber, bathed with a volume of $3.5 \mathrm{ml}$ on each side of the mucosa. The tissue was incubated at $37^{\circ} \mathrm{C}$ and shortcircuited by a computer-controlled voltage-clamp device (Ingenieur Büro für Mess- und Datentechnik Mussler, Aachen, Germany) with correction for solution resistance. Tissue conductance (Gt) was measured every min by the voltage deviation induced by a current pulse $( \pm 50 \mu \mathrm{A}$, duration $200 \mathrm{~ms})$ under opencircuit conditions. Short-circuit current (Isc) was continuously recorded on a chart-recorder. Isc is expressed as $\mu \mathrm{Eq} \cdot \mathrm{h}^{-1} \cdot \mathrm{cm}^{-2}$, i.e., the flux of a monovalent ion per time and area, with $1 \mu \mathrm{Eq} \cdot \mathrm{h}^{-1} \cdot \mathrm{cm}^{-2}=26.9 \mu \mathrm{A} \cdot \mathrm{cm}^{-2}$.

In general, one tissue served to measure the control responses evoked by at least two administrations of cysteine. The other tissue was pretreated with putative inhibitors before the second cysteine administration. If the inhibitor had to be administered in 
a solvent, the control tissue was pretreated with the solvent, too. After each cysteine administration, the serosal compartment was washed three times with five times the chamber volume.

\section{IMAGING EXPERIMENTS}

Relative changes in the cytosolic $\mathrm{pH}$ were measured using BCECF [2',7'-bis(carboxyethyl)-5,6-carboxyfluorescein/acetomethoxy methyl; Life Technologies, Darmstadt, Germany], a pH-sensitive fluorescent dye (Rink et al., 1982). The crypts were pipetted into the experimental chamber with a volume of about $3 \mathrm{ml}$. They were attached to the glass bottom of the chamber with the aid of polyL-lysine ( $0.1 \mathrm{~g} \cdot \mathrm{l}^{-1}$; Biochrom, Berlin, Germany). The crypts were incubated for $45 \mathrm{~min}$ with $8 \mu \mathrm{mol} \cdot \mathrm{l}^{-1} \mathrm{BCECF} /$ acetoxymethylester (AM). Then the dye ester not taken up by the cells was washed away. The preparation was superfused hydrostatically throughout the experiment with $140 \mathrm{mmol} \cdot \mathrm{l}^{-1} \mathrm{NaCl}$ Tyrode. Perfusion rate was about $1 \mathrm{ml} \cdot \mathrm{min}^{-1}$.

Changes in the cytosolic $\mathrm{pH}$ values were monitored as changes in the BCECF ratio ( $R$; emission at an excitation wave length of $500 \mathrm{~nm}$ divided by the emission at an excitation wave length of $450 \mathrm{~nm}$ ). For each experiment, it was waited until a stable baseline had developed before cysteine or any other substance was administered. Changes in the BCECF ratio induced by free cysteine or $\mathrm{Na}$ cysteinate are expressed as change in relation to this baseline just prior administration of cysteine or the corresponding substance ( $\triangle$ BCECF ratio). Experiments were carried out on an inverted microscope (Olympus IX-50; Olympus, Hamburg, Germany) equipped with an epifluorescence set-up and an image analysis system (Till Photonics, Martinsried, Germany). Several regions of interest, each with the size of about one cell, were placed over an individual crypt. The emission above $520 \mathrm{~nm}$ was measured from the regions of interest. Data were sampled at $0.2 \mathrm{~Hz}$. The baseline in the fluorescence ratio of BCECF was measured for several minutes before drugs were administered.

\section{DRUGS}

BCECF/AM and diallyl trisulfide (Cayman, Ann Harbor, USA) were dissolved in dimethylsulfoxide (DMSO; final maximal concentration $\left.0.3 \mathrm{ml} \cdot \mathrm{l}^{-1}\right)$. Bumetanide and forskolin were dissolved in ethanol (final maximal concentration $2.5 \mathrm{ml} \cdot \mathrm{l}^{-1}$ ). Tetrodotoxin was dissolved in $2 \times 10^{-2} \mathrm{~mol} \cdot \mathrm{l}^{-1}$ citrate buffer. Amino-oxyacetate (AOA), $\mathrm{BaCl}_{2}$, carbachol, $\beta$-cyano-L-alanine (CLA), L-cysteine, GYY 4137 ( $p$-methoxyphenyl)morpholino-phosphinodithioic acid; Cayman, Ann Harbor, USA), L-methionine, and tetrapentylammonium (TPeA) chloride were dissolved in aqueous stock solutions. Na cysteinate was prepared by dissolving free cysteine equimolarly in $1 \mathrm{~mol} \cdot \mathrm{l}^{-1} \mathrm{NaOH}$. Charybdotoxin was dissolved in an aqueous stock solution containing $1 \mathrm{~g} \cdot \mathrm{l}^{-1}$ BSA. If not indicated differently, drugs were from Sigma, Taufkirchen, Germany.

\section{STATISTICS}

Values are given as means \pm 1 SEM. In the case that means of several groups had to be compared, an analysis of variance was performed followed by post hoc test of Tukey. For the comparison of two groups, either a Student's $t$-test or a Mann Whitney $U$ test was applied. An F-test decided which test method had to be used. Both paired and unpaired two-tailed Student's $t$-tests were

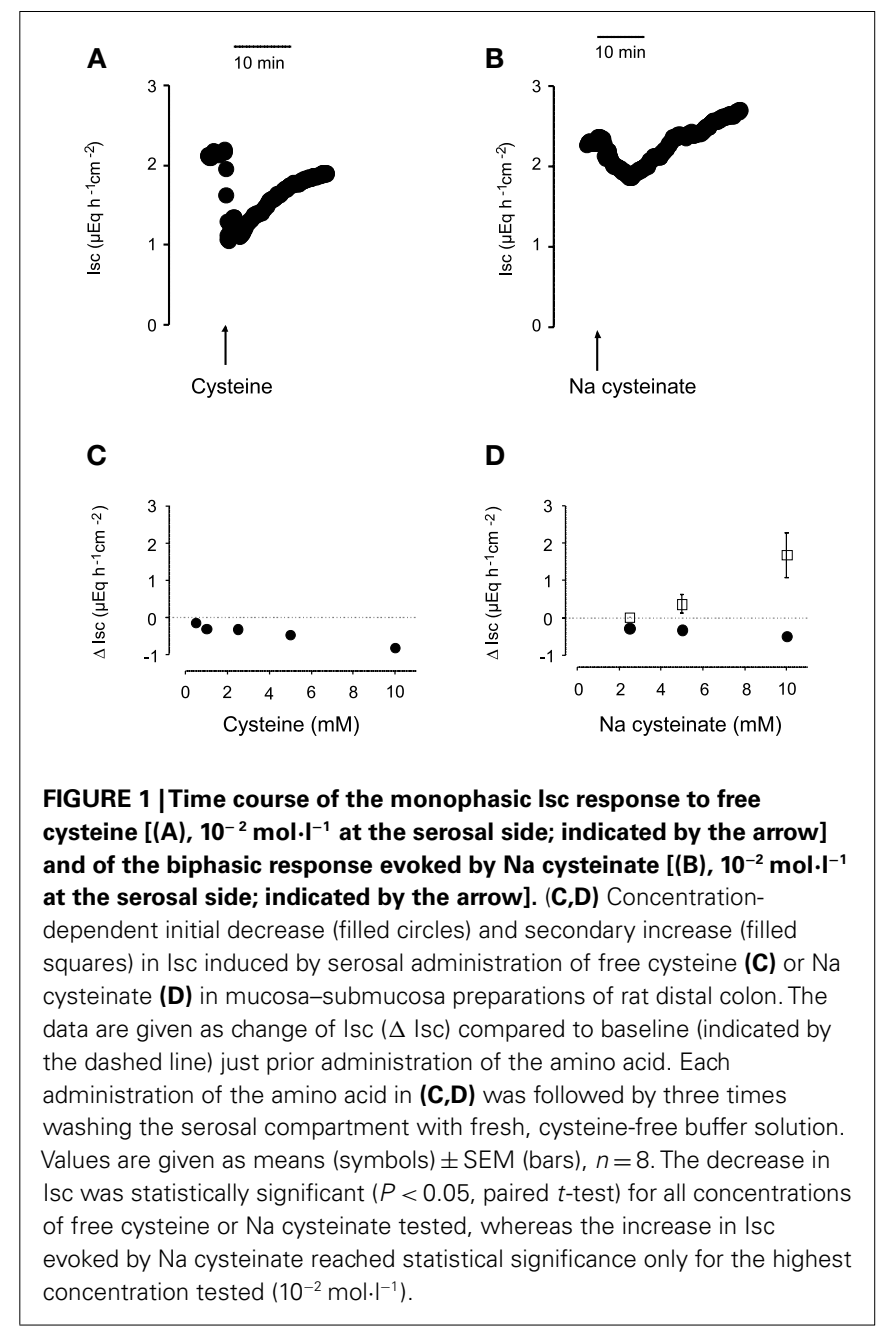

applied as appropriate. $P<0.05$ was considered to be statistically significant.

\section{RESULTS}

\section{EFFECT OF CYSTEINE ON SHORT-CIRCUIT CURRENT}

L-Cysteine, when administered to the serosal side of the tissue, induced a prompt decrease in Isc (see, e.g., Figure 1A for time course). The decrease in Isc was concentration-dependent (Figure 1C). A significant fall in baseline Isc was evoked by the lowest concentration used $\left(5 \times 10^{-4} \mathrm{~mol} \cdot \mathrm{l}^{-1}\right.$ at the serosal side $)$ and was maximal at a concentration of $10^{-2} \mathrm{~mol} \cdot \mathrm{l}^{-1}$ at the serosal side. Most of the further experiments were performed with an intermediate concentration $\left(5 \times 10^{-3} \mathrm{~mol} \cdot \mathrm{l}^{-1}\right)$ of cysteine. The decrease in Isc was not mimicked by another S-containing amino acid, L-methionine. L-Methionine, when administered at a concentration of $5 \times 10^{-3} \mathrm{~mol} \cdot \mathrm{l}^{-1}$ (at the serosal side), did not evoke a significant change in Isc $(n=8$; data not shown). Cysteine and methionine are known to block $\mathrm{K}^{+}$channels of the type TREK-1 (Park et al., 2005). The failure of methionine to mimic the cysteine response indicates that such a mechanism (or non-specific osmotic effects) cannot be the reason for the change in Isc induced by cysteine. 
A potential problem in the administration of free cysteine is the fact that this amino acid, despite the high buffer capacity of the buffer solution used, caused a fall in the $\mathrm{pH}$ of this solution, which might (and indeed does, see below) cause an acidification of the intracellular milieu (see cytosolic pH measurements below). Therefore, in a second series of experiments, cysteine was neutralized by $\mathrm{NaOH}$. When administered as $\mathrm{Na}$ cysteinate, the time course of the Isc response evoked by the amino acid changed: an initial fall, which developed slower compared to the corresponding response evoked by free cysteine, was followed by a secondary increase above the baseline, which was not observed in the case of free cysteine (Figure 1B). Both phases exhibited a clear concentration dependence (Figure 1D). When Na cysteinate $\left(5 \times 10^{-3} \mathrm{~mol} \cdot \mathrm{l}^{-1}\right)$ was administered to the mucosal side, there was no significant change in Isc ( $n=5$, data not shown).

The effect of free cysteine $\left(2.5 \times 10^{-3} \mathrm{~mol} \cdot \mathrm{l}^{-1}\right.$ at the serosal side) on Isc was significantly reduced, when the tissue was pretreated with a combination of amino-oxyacetate $\left(5 \times 10^{-3} \mathrm{~mol} \cdot \mathrm{l}^{-1}\right.$ at the serosal side $)$, an inhibitor of the enzyme cystathionine- $\beta$-synthase, and $\beta$-cyano-L-alanine $\left(5 \times 10^{-3} \mathrm{~mol} \cdot \mathrm{l}^{-1}\right.$ at the serosal side $)$, an inhibitor of the enzyme cystathionine- $\gamma$-lyase (for references to both inhibitors, see Zhao et al., 2003). In the presence of these inhibitors, cysteine only induced a fall in Isc of $-0.17 \pm 0.044 \mu \mathrm{Eq} \cdot \mathrm{h}^{-1} \cdot \mathrm{cm}^{-2}$ compared to $-0.41 \pm 0.090 \mu \mathrm{Eq} \cdot \mathrm{h}^{-1} \cdot \mathrm{cm}^{-2}$ in tissues which were - for osmotic reasons - pretreated with mannitol $\left(10^{-2} \mathrm{~mol} \cdot \mathrm{l}^{-1}\right.$ at the serosal side) instead of the two enzyme inhibitors $(n=6$, $P<0.05$; Table 1). When a higher concentration of cysteine $\left(5 \times 10^{-3} \mathrm{~mol} \cdot \mathrm{l}^{-1}\right.$ at the serosal side $)$ was used, the reduction in the cysteine response by these two blockers lost statistical significance. This observation would be consistent with the assumption of a competitive action of the two inhibitors on the $\mathrm{H}_{2} \mathrm{~S}$-producing enzymes; a mechanism of inhibition, which has indeed been shown for $\beta$-cyano-L-alanine (Pfeffer and Ressler, 1967). Also both phases of the Isc response evoked by Na cysteinate were reduced by the enzyme inhibitor combination. In the presence of the inhibitors of $\mathrm{H}_{2} \mathrm{~S}$-producing enzyme, $\mathrm{Na}$

Table 1 | Effect of free cysteine in the presence of inhibitors of $\mathrm{H}_{2} \mathrm{~S}$ synthesizing enzymes.

\begin{tabular}{lll}
\hline & \multicolumn{2}{c}{$\Delta$ Isc $\left(\mu \mathbf{E q} \cdot \mathbf{h}^{-\mathbf{1}} \cdot \mathbf{c m}^{-\mathbf{2}}\right)$} \\
\cline { 2 - 3 } & + AOA $/$ CLA & - AOA/CLA \\
\hline Free cysteine $2.5 \times 10^{-3} \mathrm{~mol} \cdot \mathrm{I}^{-1}$ & $-0.17 \pm 0.044^{*}$ & $-0.41 \pm 0.090$ \\
Free cysteine $5 \times 10^{-3} \mathrm{~mol} \cdot \mathrm{I}^{-1}$ & $-0.37 \pm 0.088$ & $-0.49 \pm 0.094$
\end{tabular}

Effect of free cysteine (at the serosal side) in the absence (-; right column) or presence ( + ; middle column) of a combination of amino-oxyacetate (AOA, $5 \times 10^{-3} \mathrm{~mol} \cdot \mathrm{H}^{-1}$ at the serosal side; cystathionine- $\beta$-synthase blocker) and $\beta$ cyano-L-alanine (CLA, $5 \times 10^{-3} \mathrm{~mol} \cdot \mathrm{I}^{-1}$ at the serosal side, cystathionine- $\gamma$-lyase blocker). The control tissues (-AOA/CLA) were treated with mannitol $\left(10^{-2} \mathrm{~mol} \cdot \mathrm{I}^{-1}\right.$ at the serosal side). Data are given as change of Isc ( $\Delta$ Isc) compared to baseline just prior administration of the respective cysteine concentration and are means $\pm S E M, n=6 .{ }^{*} P<0.05$ versus response to the same concentration of cysteine in the absence of the two enzyme inhibitors.
Table 2 | Effect of free cysteine after inhibition of $\mathrm{Cl}^{-}$secretion.

\begin{tabular}{|c|c|c|}
\hline & \multicolumn{2}{|c|}{$\begin{array}{c}\Delta \text { Isc }\left(\mu \mathrm{Eq} \cdot \mathrm{h}^{-1} \cdot \mathrm{cm}^{-2}\right) \text { evoked by } \\
\text { free cysteine }\end{array}$} \\
\hline & Control & Ilnhibitor \\
\hline $\mathrm{Cl}^{-}$free & $-0.87 \pm 0.14^{a}$ & $-0.17 \pm 0.036^{b}$ \\
\hline With $\mathrm{Cl}^{-}$ & $-0.78 \pm 0.15^{a}$ & $-0.74 \pm 0.19^{a}$ \\
\hline With bumetanide & $-0.94 \pm 0.19^{a}$ & $-0.42 \pm 0.10^{b}$ \\
\hline Without bumetanide & $-0.95 \pm 0.19^{a}$ & $-0.86 \pm 0.21^{a}$ \\
\hline
\end{tabular}

The effect of free cysteine $\left(5 \times 10^{-3} \mathrm{~mol} \cdot \mathrm{r}^{-1}\right.$ at the serosal side) on Isc was tested in the absence of any inhibitors (control), then in the presence or absence of the respective inhibitor (or replacement of $\mathrm{CF}^{-}$with the impermeable anion gluconate). The first two rows give the response to free cysteine in the absence or presence of $\mathrm{Cl}^{-}$ion in the buffer, whereas in the subsequent rows bumetanide $\left(10^{-4} \mathrm{~mol} \cdot \mathrm{I}^{-1}\right.$ at the serosal side) was used as inhibitor. Data are given as change of Isc ( $\Delta / S C)$ compared to baseline just prior administration of the respective cysteine administration and are means $\pm S E M, n=7$. Different letters $(a, b)$ indicate statistically homogenous groups (analysis of variances followed by post hoc test of Tukey).

cysteinate $\left(10^{-2} \mathrm{~mol} \cdot \mathrm{l}^{-1}\right.$ at the serosal side $)$ evoked an initial fall in Isc of only $-0.16 \pm 0.029 \mu \mathrm{Eq} \cdot \mathrm{h}^{-1} \cdot \mathrm{cm}^{-2}(n=8)$ compared to $-0.46 \pm 0.10 \mu \mathrm{Eq} \cdot \mathrm{h}^{-1} \cdot \mathrm{cm}^{-2}$ in the absence of the inhibitors $(n=8, P<0.05)$. The secondary increase in Isc evoked by $\mathrm{Na}$ cysteinate was reduced from $1.05 \pm 0.49 \mu \mathrm{Eq} \cdot \mathrm{h}^{-1} \cdot \mathrm{cm}^{-2}(n=8)$ under control conditions to $0.50 \pm 0.14 \mu \mathrm{Eq} \cdot \mathrm{h}^{-1} \cdot \mathrm{cm}^{-2}(n=8)$ in the presence of the inhibitors, although the latter difference did not reach statistical significance due to the large variation of the control response.

The negative Isc induced by cysteine did not show a desensitization. When free cysteine $\left(5 \times 10^{-3} \mathrm{~mol} \cdot \mathrm{l}^{-1}\right.$ at the serosal side $)$ was administered two times to the same tissue with a washing procedure between the individual administrations (see Materials and Methods), there was no significant decrease in the Isc response evoked by this amino acid (see, e.g., Tables 2 and 4, control responses). The same was observed for the biphasic change in Isc induced by Na cysteinate, which could be repetitively evoked at the same tissue without a reduction in either the initial fall nor in the final increase in Isc (see Table 3, control responses). In contrast, there was even a tendency (especially for Na cysteinate) that the second administration of the amino acid evoked larger changes in Isc than the first administration; a phenomenon, however, which was not studied further here.

Consequently, for all inhibitor experiments designed to clarify the mechanism of action of cysteine the following protocol was used. The response to cysteine was first measured in each tissue under control conditions, i.e., in the absence of other drugs. After a washing step, the response evoked by cysteine was measured in the presence of a putative inhibitor.

\section{A CHANGE IN Cl- SECRETION UNDERLIES THE CYSTEINE-INDUCED ISC}

The negative Isc induced by free cysteine can, in principle, be caused by two mechanisms: an inhibition of spontaneous $\mathrm{Cl}^{-}$ secretion, which is responsible for the generation of the positive baseline Isc in rat colon (see, e.g., Strabel and Diener, 1995), 
$\Delta$ Isc $\left(\mu \mathrm{Eq} \cdot \mathrm{h}^{-1} \cdot \mathrm{cm}^{-2}\right)$ evoked by Na cysteinate

\begin{tabular}{|c|c|c|c|c|}
\hline & \multicolumn{2}{|c|}{ Control } & \multicolumn{2}{|c|}{ \pm Inhibitor } \\
\hline & Initial decrease & Peak & Initial decrease & Peak \\
\hline With $+\mathrm{Cl}^{-}$ & $-0.81 \pm 0.26^{a}$ & $-0.11 \pm 0.25^{\mathrm{a}}$ & $-0.59 \pm 0.16^{a}$ & $0.72 \pm 0.26^{b}$ \\
\hline With bumetanide & $-0.49 \pm 0.25^{a, b}$ & $0.23 \pm 0.21^{b}$ & $-0.23 \pm 0.016^{a}$ & $-0.021 \pm 0.090^{a}$ \\
\hline Without bumetanide & $-0.68 \pm 0.13^{a, b}$ & $0.37 \pm 0.22^{a}$ & $-1.12 \pm 0.16^{b}$ & $0.85 \pm 0.61^{a}$ \\
\hline
\end{tabular}

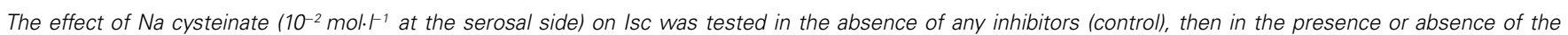

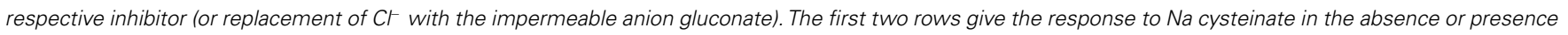

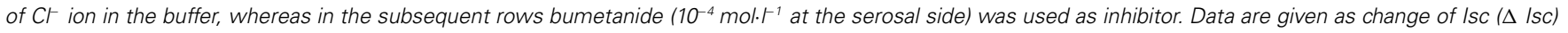

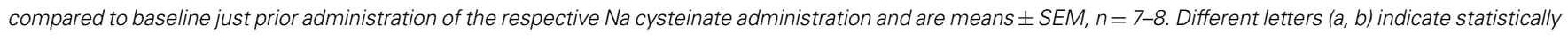
homogenous groups (analysis of variances followed by post hoc test of Tukey).

or the induction of the secretion of cations, i.e., the induction of $\mathrm{K}^{+}$secretion (see, e.g., Hörger et al., 1998). The negative Isc evoked by free cysteine was strongly dependent on the presence of $\mathrm{Cl}^{-}$. In the presence of $\mathrm{Cl}^{-}$, cysteine $\left(5 \times 10^{-3} \mathrm{~mol} \cdot \mathrm{l}^{-1}\right.$ at the serosal side) evoked a fall in Isc of $-0.87 \pm 0.14 \mu \mathrm{Eq} \cdot \mathrm{h}^{-1} \cdot \mathrm{cm}^{-2}$. This change in Isc was reduced by about $80 \%$, when the amino acid was administered to the same tissue after substitution of $\mathrm{Cl}^{-}$ by the impermeant anion, gluconate, on both sides of the tissue (Table 2). Similarly, both the initial fall as well as the secondary increase in Isc evoked by Na cysteinate $\left(10^{-2} \mathrm{~mol} \cdot \mathrm{l}^{-1}\right.$ at the serosal side) were significantly reduced in the absence of $\mathrm{Cl}^{-}$(Table 3).

A significant inhibition of the cysteine-evoked Isc was also observed, when the $\mathrm{Na}^{+}-\mathrm{K}^{+}-2 \mathrm{Cl}^{-}$-cotransporter, the dominant $\mathrm{Cl}^{-}$-loading mechanism in the basolateral membrane necessary to maintain transepithelial $\mathrm{Cl}^{-}$secretion (Kaplan et al., 1996), was blocked with bumetanide $\left(10^{-4} \mathrm{~mol} \cdot \mathrm{l}^{-1}\right.$ at the serosal side; Figure 2 and Table 2). Bumetanide inhibited the biphasic change in Isc induced by $\mathrm{Na}$ cysteinate $\left(10^{-2} \mathrm{~mol} \cdot \mathrm{l}^{-1}\right.$ at the serosal side) to a similar extent (Table 3 ).

The further experiments, which served to elucidate the potential role of changes in $\mathrm{K}^{+}$transport in the negative Isc evoked by the amino acid were performed only with free cysteine in order to avoid any contamination of the measured currents with the secondary increase in Isc, i.e., the parallel induction of $\mathrm{Cl}^{-}$secretion observed with $\mathrm{Na}$ cysteinate. In contrast to two maneuvers interfering with $\mathrm{Cl}^{-}$secretion (i.e., anion substitution and inhibition of the $\mathrm{Na}^{+}-\mathrm{K}^{+}-2 \mathrm{Cl}^{-}$-cotransporter), inhibition of apical $\mathrm{K}^{+}$channels, which are a prerequisite for colonic $\mathrm{K}^{+}$secretion (SØrensen et al., 2010), did not change the cysteine response. None of the $\mathrm{K}^{+}$channel blockers tested (for references to these $\mathrm{K}^{+}$channel blockers, see Cook and Quast, 1990) had any significant effect on the Isc evoked by free cysteine. Neither $\mathrm{Ba}^{2+}$ $\left(10^{-2} \mathrm{~mol} \cdot \mathrm{l}^{-1}\right.$ at the mucosal side), a broad $\mathrm{K}^{+}$channel blocker affecting many types of $\mathrm{K}^{+}$channels, nor tetrapentylammonium $\left(10^{-4} \mathrm{~mol} \cdot \mathrm{l}^{-1}\right.$ at the mucosal side), a blocker with some preference for $\mathrm{Ca}^{2+}$-dependent $\mathrm{K}^{+}$channels (Maguire et al., 1999), nor charybdotoxin $\left(2 \times 10^{-7} \mathrm{~mol} \cdot \mathrm{l}^{-1}\right.$ at the mucosal side $)$, a selective blocker of large-conductance $\left(\mathrm{BK}_{\mathrm{Ca}}\right) \mathrm{Ca}^{2+}$-dependent $\mathrm{K}^{+}$ channels (Berkefeld et al., 2010), had any significant effect on the
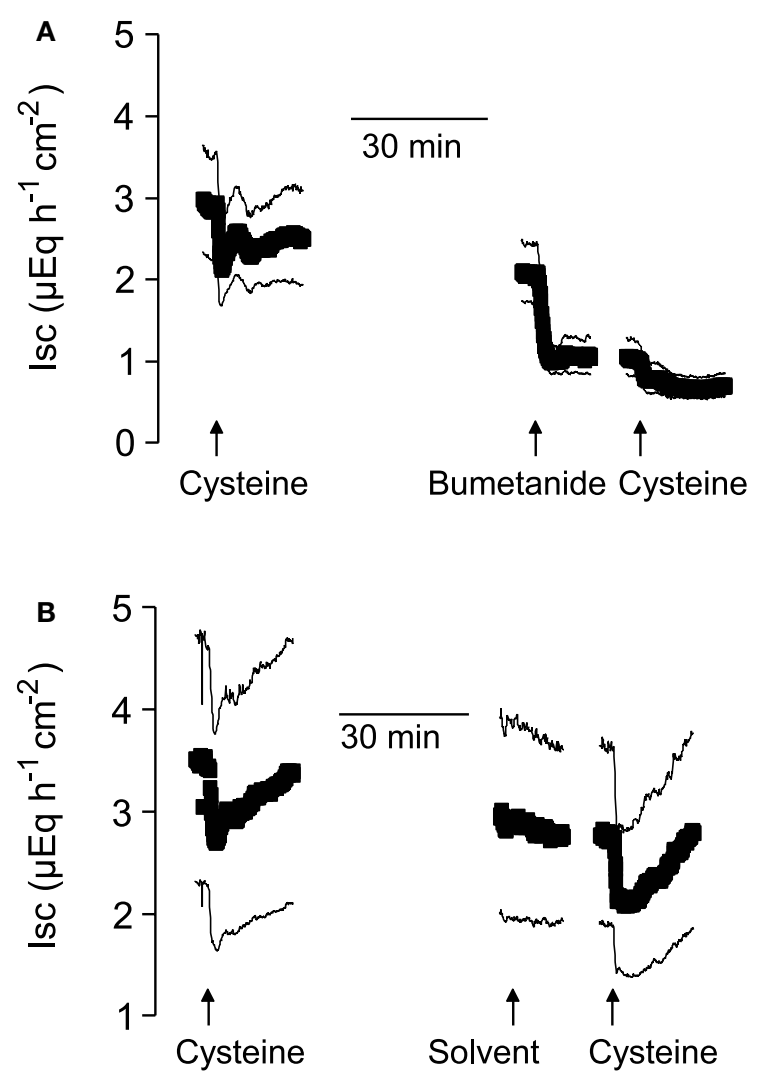

FIGURE 2 | After suppression of $\mathrm{Cl}^{-}$secretion with bumetanide, the action of cysteine is prevented. Shown are the effects of two administrations of free cysteine $\left(5 \times 10^{-3} \mathrm{~mol} \cdot \mathrm{l}^{-1}\right.$ at the serosal side; indicated by the arrows) in mucosa-submucosa preparations of rat distal colon. The line interruptions are caused by omission of current artifacts induced by washing the serosal compartment three times with five times the chamber volume, before the next administration of cysteine followed. The effect of cysteine was first tested in the absence of any inhibitors and then in the presence $\mathbf{( A )}$ or absence $\mathbf{( B )}$ of bumetanide $\left(10^{-4} \mathrm{~mol} \cdot \mathrm{I}^{-1}\right.$ at the serosal side). The solvent for bumetanide (ethanol) was administered to the tissues which were not treated with bumetanide. Values are means (symbols) \pm SEM (lines), $n=7$. For statistics, see Table 2. 
negative Isc induced by free cysteine (Table 4). Consequently, these data allow the conclusion that the negative Isc evoked by cysteine is caused by an inhibition of spontaneous anion secretion and not due to an activation of transepithelial $\mathrm{K}^{+}$secretion.

This conclusion was corroborated by experiments in which $\mathrm{K}^{+}$channel blockers were administered to the serosal side of the tissue. A sufficient basolateral $\mathrm{K}^{+}$conductance is necessary to maintain basal membrane potential as driving force for $\mathrm{Cl}^{-}$exit across apical $\mathrm{Cl}^{-}$channels (Strabel and Diener, 1995). Blockade

Table 4 | Effect of free cysteine after blockade of $\mathrm{K}^{+}$channels.

\begin{tabular}{lll}
\hline & \multicolumn{2}{c}{$\boldsymbol{\Delta}$ Isc $\left(\boldsymbol{\mu} \mathbf{E q} \cdot \mathbf{h}^{\left.\mathbf{- 1} \cdot \mathbf{c m}^{-\mathbf{2}}\right) \text { evoked free cysteine }}\right.$} \\
\cline { 2 - 3 } & Control & \pm Inhibitor \\
\hline With serosal Ba ${ }^{2+}$ & $-1.30 \pm 0.17^{\mathrm{a}}$ & $-0.78 \pm 0.10^{\mathrm{b}}$ \\
Without serosal Ba ${ }^{2+}$ & $-1.57 \pm 0.19^{\mathrm{a}}$ & $-2.02 \pm 0.40^{\mathrm{a}}$ \\
With serosal TPeA & $-0.58 \pm 0.12^{\mathrm{a}}$ & $-0.18 \pm 0.039^{\mathrm{b}}$ \\
Without serosal TPeA & $-0.82 \pm 0.13^{\mathrm{a}}$ & $-1.14 \pm 0.28^{\mathrm{a}}$ \\
With serosal CTX & $-1.01 \pm 0.11^{\mathrm{a}}$ & $-0.86 \pm 0.13^{\mathrm{a}}$ \\
Without serosal CTX & $-0.81 \pm 0.1^{\mathrm{a}}$ & $-0.62 \pm 0.098^{\mathrm{a}}$ \\
With mucosal Ba & $-0.89 \pm 0.082^{\mathrm{a}}$ & $-1.64 \pm 0.30^{\mathrm{a}, \mathrm{b}}$ \\
Without mucosal Ba & $-0.80 \pm 0.078^{\mathrm{a}}$ & $-1.30 \pm 0.098^{\mathrm{b}}$ \\
With mucosal TPeA & $-0.56 \pm 0.10^{\mathrm{a}}$ & $-0.63 \pm 0.13^{\mathrm{a}}$ \\
Without mucosal TPeA & $-0.61 \pm 0.067^{\mathrm{a}}$ & $-0.59 \pm 0.093^{\mathrm{a}}$ \\
With mucosal CTX & $-0.79 \pm 0.096^{\mathrm{a}}$ & $-0.56 \pm 0.046^{\mathrm{a}, \mathrm{b}}$ \\
Without mucosal CTX & $-0.78 \pm 0.087^{\mathrm{a}}$ & $-0.75 \pm 0.15^{\mathrm{a}}$
\end{tabular}

The effect of free cysteine $\left(5 \times 10^{-3} \mathrm{~mol} \cdot \mathrm{H}^{-1}\right.$ at the serosal side) on Isc was tested in the absence of any inhibitors (control) and then in the presence or absence of the respective inhibitor. The following $\mathrm{K}^{+}$channel blockers were applied either at the serosal or the mucosal side: $B a^{2+}\left(10^{-2} \mathrm{~mol} \cdot \mathrm{r}^{-1}\right)$, tetrapentylammonium (TPeA; $\left.10^{-4} \mathrm{~mol} \cdot .^{-1}\right)$, and charybdotoxin $\left(\mathrm{CTX} ; 2.10^{-7} \mathrm{~mol} \cdot .^{-1}\right)$. The experiments with $\mathrm{Ba}^{2+}$ were performed in $\mathrm{HCO}_{3}^{-}$-free Tyrode buffer solution in order to avoid precipitation of Ba carbonate. The reason for the apparent enhancement of the cysteine response in this buffer is unknown. Data are given as change of Isc ( $\Delta$ IsC) compared to baseline just prior administration of the respective cysteine administration and are means $\pm S E M, n=7-8$. Different letters $(a, b)$ indicate statistically homogenous groups (analysis of variances followed by post hoc test of Tukey). of basolateral $\mathrm{K}^{+}$channels with $\mathrm{Ba}^{2+}\left(10^{-2} \mathrm{~mol} \cdot \mathrm{l}^{-1}\right.$ at the serosal side) or tetrapentylammonium $\left(10^{-4} \mathrm{~mol} \cdot \mathrm{l}^{-1}\right.$ at the serosal side) significantly inhibited the negative Isc evoked by free cysteine. In contrast, charybdotoxin $\left(2 \times 10^{-7} \mathrm{~mol} \cdot \mathrm{l}^{-1}\right.$ at the serosal side $)$ was ineffective (Table 4). In these series of experiments with $\mathrm{K}^{+}$channel blockers, a clear tendency for increased cysteine effects was observed in the experiments designed to measure the effect of $\mathrm{Ba}^{2+}$. The reason for this discrepancy to the other experimental series may be that these experiments were performed in $\mathrm{HCO}_{3}^{-}$free, HEPES buffered Tyrode solution (in order to avoid precipitation of $\mathrm{Ba}^{2+}$ as carbonate or sulfate salt). This phenomenon, however, was not studied further.

\section{DO ENTERIC NEURONS PARTICIPATE IN THE RESPONSE TO CYSTEINE?}

Immunohistochemical experiments have demonstrated that the $\mathrm{H}_{2} \mathrm{~S}$-producing enzymes, cystathionine- $\beta$-synthase and cystathionine- $\gamma$-lyase, are expressed within the epithelium, but also in muscle cells and neurons (Schicho et al., 2006; Hennig and Diener, 2009). Consequently, it seemed to be of interest whether enteric neurons might mediate the response evoked by cysteine. The effect of free cysteine $\left(5 \times 10^{-3} \mathrm{~mol} \cdot \mathrm{l}^{-1}\right.$ at the serosal side) on Isc was unaffected when neuronal activity was blocked with tetrodotoxin $\left(10^{-6} \mathrm{~mol} \cdot \mathrm{l}^{-1}\right.$ at the serosal side $)$, a blocker of voltage-dependent neuronal $\mathrm{Na}^{+}$channels (Table 5). The same resistance against tetrodotoxin was observed with $\mathrm{Na}$ cysteinate $\left(5 \times 10^{-3} \mathrm{~mol} \cdot \mathrm{l}^{-1}\right.$ at the serosal side; Table 5$)$. Consequently, cysteine obviously does not act via modulation of the activity of secretomotor submucosal neurons present in the mucosa-submucosa preparations used in this study.

\section{EFFECTS OF CYSTEINE ON CYTOSOLIC pH}

L-Cysteine is a weak acid, which causes - despite the relative high buffer capacity of the $\mathrm{HCO}_{3}^{-}$/phosphate buffer used, an acidification of the extracellular solution, which might affect transepithelial transport. Administration of free cysteine in a concentration of $2.5 \times 10^{-3} \mathrm{~mol} \cdot \mathrm{l}^{-1}$ or $5 \times 10^{-3} \mathrm{~mol} \cdot \mathrm{l}^{-1}$ induced an acute fall in $\mathrm{pH}$ to 7.03 or 6.82 , respectively. In order to find out whether a proton release might occur intracellularly after cellular uptake of cysteine, experiments were carried out with BCECF-loaded

Table 5 | Effect of cysteine after neuronal blockade.

\begin{tabular}{|c|c|c|c|c|}
\hline & \multicolumn{2}{|c|}{ Control } & \multicolumn{2}{|c|}{ \pm Inhibitor } \\
\hline & Initial decrease & Peak & Initial decrease & Peak \\
\hline \multicolumn{5}{|c|}{$\Delta$ Isc $\left(\mu \mathrm{Eq} \cdot \mathrm{h}^{-1} \cdot \mathrm{cm}^{-2}\right)$ EVOKED BY FREE CYSTEINE } \\
\hline With tetrodotoxin & $-0.56 \pm 0.11^{\mathrm{a}}$ & - & $-0.56 \pm 0.16^{a}$ & - \\
\hline Without tetrodotoxin & $-0.45 \pm 0.069^{a}$ & - & $-0.47 \pm 0.078^{\mathrm{a}}$ & - \\
\hline \multicolumn{5}{|c|}{$\Delta$ Isc $\left(\mu \mathrm{Eq} \cdot \mathrm{h}^{-1} \cdot \mathrm{cm}^{-2}\right)$ EVOKED BY Na CYSTEINATE } \\
\hline Without tetrodotoxin & $-0.308 \pm 0.075^{a}$ & $0.064 \pm 0.077^{a}$ & $-0.305 \pm 0.132^{\mathrm{a}}$ & $0.782 \pm 0.207^{b}$ \\
\hline
\end{tabular}

The effect of free cysteine $\left(5 \times 10^{-3} \mathrm{~mol} \cdot \mathrm{t}^{-1}\right.$ at the serosal side, upper two rows) and Na cysteinate $\left(5 \times 10^{-3} \mathrm{~mol} \cdot \mathrm{I}^{-1}\right.$ at the serosal side, lower two rows) on Isc was tested in the absence of any inhibitors (control) and then in the presence or absence of tetrodotoxin $\left(10^{-6}\right.$ mol..$^{-1}$ at the serosal side). Data are given as change of Isc $(\Delta / s c)$ compared to baseline just prior administration of the respective cysteine administration and are means $\pm S E M, n=6$. Different letters (a, b) indicate statistically homogenous groups (analysis of variances followed by post hoc test of Tukey). 


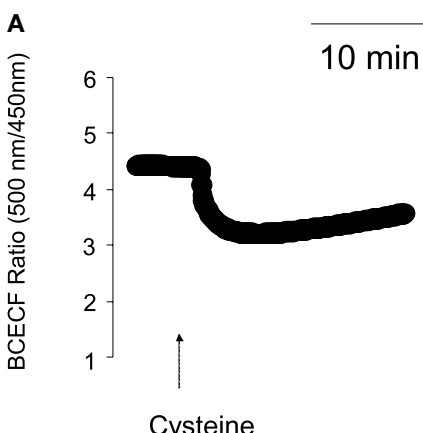

FIGURE 3 | (A) Cysteine, but not Na cysteinate induces a cytosolic acidification. Free cysteine $\left(10^{-2} \mathrm{~mol} \cdot \mathrm{I}^{-1}\right.$; indicated by the arrow) induced a fall in the BCECF ratio signal. Values are given as means (symbols) \pm SEM (lines), $n=72$. (B) The response was not mimicked by Na cysteinate $\left(10^{-2} \mathrm{~mol} \cdot \mathrm{I}^{-1}\right.$;

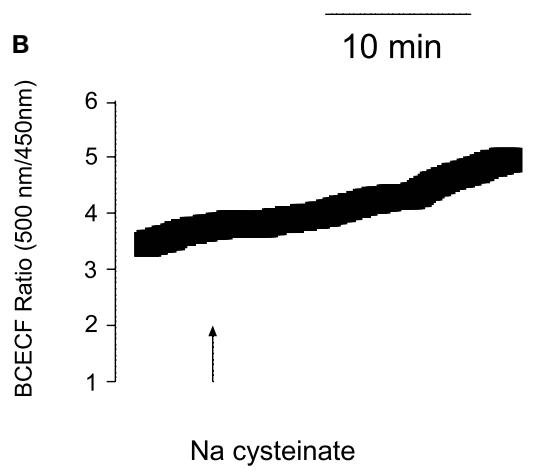

indicated by the arrow). Values are given as means (symbols) \pm SEM (lines), $n=97$. In both cases, the ratio signal (emission at an excitation wave length of $500 \mathrm{~nm}$ divided by the emission at an excitation wave length of $450 \mathrm{~nm}$ ) was measured at isolated colonic crypts. isolated crypts. The fluorescence ratio signal of this dye decreases, when the cytosolic $\mathrm{pH}$ falls.

In deed, free cysteine $\left(10^{-2} \mathrm{~mol} \cdot \mathrm{l}^{-1}\right)$ induced a prompt decrease in the BCECF ratio signal indicating cytosolic acidification (Figure 3). This fall was followed by a slow recovery, probably due to cellular $\mathrm{pH}$ counter-regulation. Such a phenomenon was not observed with $\mathrm{Na}$ cysteinate $\left(10^{-2} \mathrm{~mol} \cdot \mathrm{l}^{-1}\right.$; Figure 3B). The sensitivity of different types of $\mathrm{K}^{+}$channels to cellular acidification is well known, also from isolated rat colonic crypts (Diener and Scharrer, 1994), and might be responsible for the different effects evoked by free cysteine in comparison to $\mathrm{Na}$ cysteinate (see Discussion). In deed, when the serosal buffer solution was acidified by administration of $\mathrm{HCl}$ to similar values as reached by administration of free cysteine, this caused a prompt fall in Isc of $0.95 \pm 0.22 \mu \mathrm{Eq} \cdot \mathrm{h}^{-1} \cdot \mathrm{cm}^{-2}(n=7, P<0.05$ versus baseline) in the case of an acidification to a $\mathrm{pH}$ of 7.0 and of $0.96 \pm 0.13 \mu \mathrm{Eq} \cdot \mathrm{h}^{-1} \cdot \mathrm{cm}^{-2}(n=7, P<0.05$ versus baseline $)$ in the case of an acidification to a $\mathrm{pH}$ of 6.8. In no case, however, a secondary rise in Isc was observed as it was the case when Na cysteinate was administered.

\section{COMPARISON WITH OTHER $\mathrm{H}_{2} \mathrm{~S}$ DONORS}

The divergent response in Isc evoked by $\mathrm{Na}$ cysteinate, which induces a biphasic change in Isc, compared to NaHS, which stimulates a triphasic change in Isc, suggests that the speed of $\mathrm{H}_{2} \mathrm{~S}$ release might affect the biological effect at the colonic epithelium. In order to test this hypothesis in more detail, two other $\mathrm{H}_{2} \mathrm{~S}$-releasing molecules were used (for references to these donors, see Martelli et al., 2011). GYY 4137 $\left(5 \times 10^{-5} \mathrm{~mol} \cdot \mathrm{l}^{-1}\right.$ at the serosal side $)$, a very slow $\mathrm{H}_{2} \mathrm{~S}$-releasing molecule, did not evoke any increase in Isc. Instead, a slow fall in Isc was observed which appeared to be faster than the usual time-dependent decrease in Isc observed over prolonged time-periods in mucosa-submucosa preparations of rat distal colon (Figure 4A). In contrast, diallyl trisulfide, a compound found in garlic, which is converted intracellularly to $\mathrm{H}_{2} \mathrm{~S}$ by reaction with glutathione, evoked a monophasic increase in Isc in all concentrations tested (up to $1.5 \times 10^{-4} \mathrm{~mol} \cdot \mathrm{l}^{-1}$ at the serosal side). When administered in a concentration of
$1.5 \times 10^{-5} \mathrm{~mol} \cdot \mathrm{l}^{-1}$ at the serosal side, diallyl trisulfide evoked an increase of $0.89 \pm 0.22 \mu \mathrm{Eq} \cdot \mathrm{h}^{-1} \cdot \mathrm{cm}^{-2}$ above baseline $(P<0.05$, $n=7$; Figure $4 \mathrm{~B})$. In contrast, a roughly equieffective concentration of the fast $\mathrm{H}_{2} \mathrm{~S}$ donor, NaHS $\left(2.5 \times 10^{-3} \mathrm{~mol} \cdot \mathrm{l}^{-1}\right.$ at the serosal side), evoked the typical multiphasic change in Isc as reported earlier (Hennig and Diener, 2009), i.e., a quick increase in Isc by $1.06 \pm 0.14 \mu \mathrm{Eq} \cdot \mathrm{h}^{-1} \cdot \mathrm{cm}^{-2}$ above baseline $(P<0.05$, $n=7)$, followed by a transient fall and finally a secondary increase of $1.60 \pm 0.22 \mu \mathrm{Eq} \cdot \mathrm{h}^{-1} \cdot \mathrm{cm}^{-2}$ above baseline $(P<0.05, n=7$; Figure 4B). Consequently, three different $\mathrm{H}_{2} \mathrm{~S}$-releasing drugs evoked different patterns of Isc responses across the colonic mucosa.

\section{INTERACTIONS WITH SECRETAGOGUES}

As cysteine modulates basal anion secretion (Figure 1), it seemed to be of interest to study whether this activator of endogenous $\mathrm{H}_{2} \mathrm{~S}$ synthesis might be able to interfere with the response of the epithelium to secretagogues. $\mathrm{Ca}^{2+}$-dependent secretagogues such as the stable acetylcholine derivate, carbachol, typically induce a strong, but only transient increase in Isc (see, e.g., Strabel and Diener, 1995). Therefore, the effect of $\mathrm{Na}$ cysteinate on the carbachol response was measured by pretreatment with this amino acid. In the absence of $\mathrm{Na}$ cysteinate, carbachol evoked an increase in Isc of $9.11 \pm 1.62 \mu \mathrm{Eq} \cdot \mathrm{h}^{-1} \cdot \mathrm{cm}^{-2}(n=6)$, which only amounted to $6.84 \pm 1.83 \mu \mathrm{Eq} \cdot \mathrm{h}^{-1} \cdot \mathrm{cm}^{-2}$ in the presence of Na cysteinate $\left(5 \times 10^{-5} \mathrm{~mol} \cdot \mathrm{l}^{-1}\right.$ at the serosal side, $n=6$, Figures $\left.5 \mathbf{A}, \mathbf{B}\right)$, although this difference did not reach statistical significance. Similar experiments were performed with free cysteine. In the absence of free cysteine, carbachol $\left(5 \times 10^{-5} \mathrm{~mol} \cdot \mathrm{l}^{-1}\right.$ at the serosal side) evoked an increase in Isc above baseline which amounted to $7.66 \pm 0.63 \mu \mathrm{Eq} \cdot \mathrm{h}^{-1} \cdot \mathrm{cm}^{-2}(n=6)$. In contrast, after pretreating the tissue with free cysteine $\left(5 \times 10^{-3} \mathrm{~mol} \cdot \mathrm{l}^{-1}\right.$ at the serosal side), Isc increased by only $4.20 \pm 1.02 \mu \mathrm{Eq} \cdot \mathrm{h}^{-1} \cdot \mathrm{cm}^{-2} \quad(n=7$, $P<0.05$ versus response to carbachol in the absence of free cysteine).

In contrast to $\mathrm{Ca}^{2+}$-dependent secretagogues, stimulation of the cAMP-pathway with forskolin, an activator of adenylate cyclase(s) (Seamon and Daly, 1981), leads to a stable increase in Isc (see Figure 5D), so that cysteine could be administered 

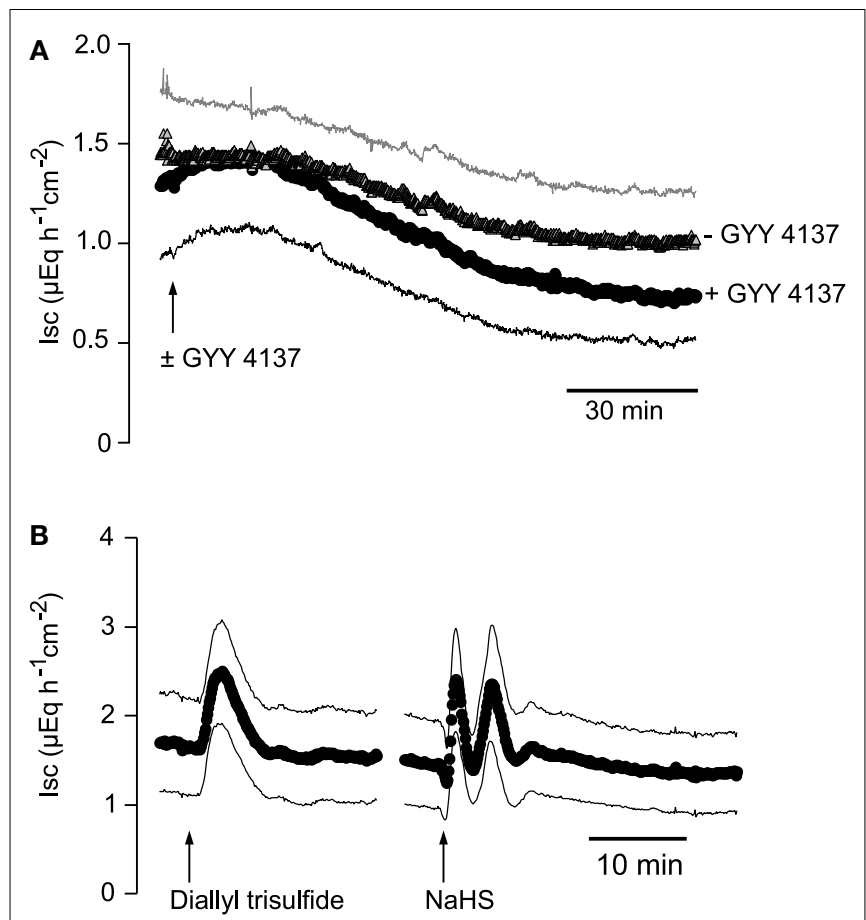

FIGURE 4 | (A) Comparison of the Isc evoked by different $\mathrm{H}_{2} \mathrm{~S}$ donors. The very slow $\mathrm{H}_{2}$ S-releasing molecule, GYY $4137\left(5 \times 10^{-5} \mathrm{~mol} \cdot \mathrm{I}^{-1}\right.$ at the serosal side; arrow; black symbols and curve marked with + GYY 4137), did not evoke an increase in Isc in mucosa-submucosa preparations of rat distal colon. In contrast, a slow decrease in Isc, which had the tendency (not statistically significant) to be more pronounced compared to time-dependent control experiments (- GYY 4137) not pretreated with GYY 4137 (gray symbols) was observed. (B) The slow $\mathrm{H}_{2} \mathrm{~S}$ donor, diallyl trisulfide $\left(1.5 \times 10^{-5} \mathrm{~mol} \cdot \mathrm{I}^{-1}\right.$ at the serosal side; left arrow $)$, causes a transient, monophasic increase in Isc, whereas the fast $\mathrm{H}_{2} \mathrm{~S}$ donor, $\mathrm{NaHS}$, administered in an equieffective concentration $\left(2.5 \times 10^{-3} \mathrm{~mol} \cdot \mathrm{I}^{-1}\right.$ at the serosal side; right arrow), induced a triphasic change in Isc. Values are means (symbols) \pm SEM (lines), $n=5-7$. In the case of the experiments with GYY 4137, for graphical reasons for the time-dependent control experiments (- GYY 4137) only +SEM (gray line) and for the group treated with GYY 4137 (+ GY 4137) only -SEM (black line) are shown. For statistics, see text.

during the plateau phase of the current induced by forskolin $\left(5 \times 10^{-6} \mathrm{~mol} \cdot \mathrm{l}^{-1}\right.$ at the mucosal and the serosal side $)$. Under these conditions, Na cysteinate only evoked a transient and small decrease in Isc (Figure 5C). A similar response was observed with free cysteine. For example, administration of free cysteine in a concentration of $5 \times 10^{-3} \mathrm{~mol} \cdot \mathrm{l}^{-1}$ (at the serosal side) induced a transient decrease of the forskolin-induced Isc by $-0.55 \pm 0.028 \mu \mathrm{Eq} \cdot \mathrm{h}^{-1} \cdot \mathrm{cm}^{-2}(n=7)$, which is not larger than the effect of cysteine on baseline Isc in the absence of forskolin (see e.g. control series in Table 2 and Table 4). So similar as it was observed with another gasotransmitter, carbon monoxide (Steidle and Diener, 2011), which when given alone evokes anion secretion but reduces the carbachol-induced Isc, also hydrogen sulfide impairs $\mathrm{Ca}^{2+}$-dependent secretion, probably because both gasotransmitters interfere with intracellular $\mathrm{Ca}^{2+}$ signaling (Hennig and Diener, 2009; Pouokam and Diener, 2011; Steidle and Diener, 2011).

\section{DISCUSSION}

Hydrogen sulfide is recognized as a neurotransmitter in the enteric nervous system, i.e., the central regulator responsible for the control of most gastrointestinal functions (Jimenez, 2010). Expression of cystathionine- $\beta$-synthase and cystathionine- $\gamma$-lyase, the key enzymes for $\mathrm{H}_{2} \mathrm{~S}$ production (Wang, 2002), in smooth muscle and in epithelial cells from rat colon suggests additional paracrine actions of this gaseous molecule (Hennig and Diener, 2009). As stated in the Introduction, the biological role of $\mathrm{H}_{2} \mathrm{~S}$ during inflammatory processes is discussed controversially because this gasotransmitter has been reported to aggravate (see, e.g., Chávez-Piña et al., 2010) as well as to ameliorate (see, e.g., Fiorucci et al., 2007; Wallace et al., 2009) inflammatory processes. The observation that the exogenous $\mathrm{H}_{2} \mathrm{~S}$ donor NaHS evokes a strong $\mathrm{Cl}^{-}$secretion across the colon of different species in vitro (Schicho et al., 2006; Hennig and Diener, 2009), i.e., would finally induce secretory diarrhoe in vivo, is - at first glance - in contradiction to the observed therapeutic effect of a $\mathrm{H}_{2} \mathrm{~S}$-releasing mesalamine-derivative (ATB-429) in a model of mouse colitis (Fiorucci et al., 2007). Interestingly, a similar controversy about pro/antiinflammatory or proabsorptive/prosecretory actions exists for a second gasotransmitter, NO (see, e.g., SchirgiDegen and Beubler, 1995; Schultheiss et al., 2002), suggesting that depending on differences in time, location, or amplitude of the production of these gasotransmitters the physiological response may differ in a fundamental way.

The present results demonstrate that cysteine (especially when administered as $\mathrm{Na}$ cysteinate), the precursor for endogenous $\mathrm{H}_{2} \mathrm{~S}$ synthesis, has a biphasic effect on anion secretion: an initial decrease followed by prolonged increase in Isc above the former baseline (Figure 1B). This second phase, i.e., a rise above the former baseline, is missing in the case of free cysteine (Figure 1A). Most probably the intracellular acidification, which is evoked by free cysteine, but not by $\mathrm{Na}$ cysteinate (Figure 3), is responsible for the missing ability of the presumed stimulation of $\mathrm{H}_{2} \mathrm{~S}$ synthesis to induce anion secretion (see below). Plasma cysteine concentrations in human blood are in the range of $0.3 \mathrm{mmol} \cdot \mathrm{l}^{-1}$ (Van den Brandhof et al., 2001). So the concentrations used in the present study are clearly above physiological level. However, our aim was not mimic the physiological situation, but to stimulate maximally endogenous $\mathrm{H}_{2} \mathrm{~S}$ production, which is shown here by the amino-oxyacetate- and $\beta$-cyano- $\mathrm{L}$-alanine-sensitive changes in Isc.

Both phases of the response to $\mathrm{Na}$ cysteinate, i.e., the initial fall as well as the secondary rise in Isc, were inhibited in the presence of bumetanide or after substitution of $\mathrm{Cl}^{-}$by an impermeant anion confirming the modulation of $\mathrm{Cl}^{-}$secretion by Na cysteinate (Table 3). This response differs from the change in Isc evoked by the exogenous $\mathrm{H}_{2} \mathrm{~S}$ donor, NaHS, which evokes a polyphasic $\mathrm{Cl}^{-}$secretion in the same tissue (Hennig and Diener, 2009). Theoretically, the negative Isc induced by cysteine might also be caused by the activation of $\mathrm{K}^{+}$secretion, as both an inhibition of anion secretion as well as a stimulation of cation secretion exert the same effect on the transepithelial potential difference, i.e., the serosal side gets less positive. However, none of the $\mathrm{K}^{+}$channel blockers tested $\left(\mathrm{Ba}^{2+}\right.$, tetrapentylammonium, or charybdotoxin), 


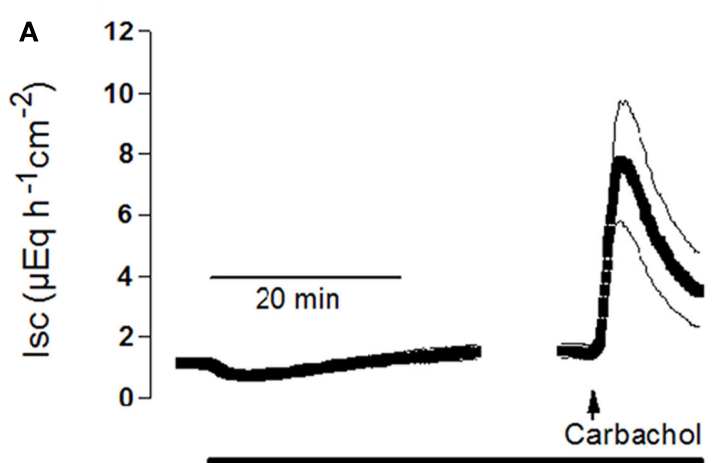

Na Cysteinate

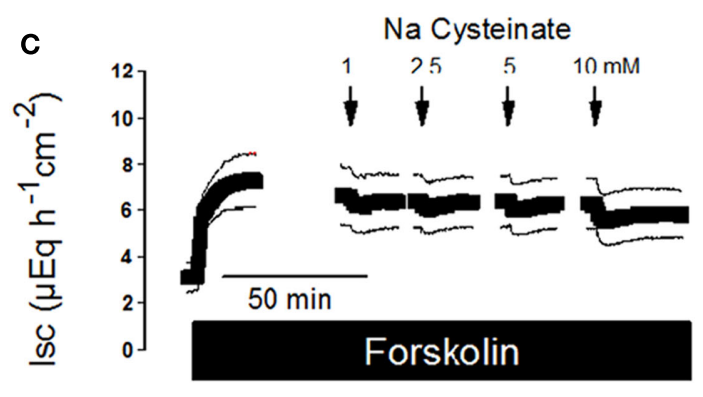

FIGURE 5 | (A) Interaction of Na cysteinate with the Isc evoked by secretagogues. Pretreatment with Na cysteinate $\left(5 \times 10^{-3} \mathrm{~mol} \cdot \mathrm{I}^{-1}\right.$ at the serosal side; black bar) slightly reduced the increase in Isc evoked by carbachol $\left(5 \times 10^{-5} \mathrm{~mol} \cdot \mathrm{l}^{-1}\right.$ at the serosal side; arrow) in mucosa-submucosa preparations of rat distal colon compared to a time-dependent control not treated with $\mathrm{Na}$ cysteinate (B). (C) Na cysteinate $\left(10^{-3}\right.$ to $10^{-2} \mathrm{~mol} \cdot \mathrm{I}^{-1}$ at the
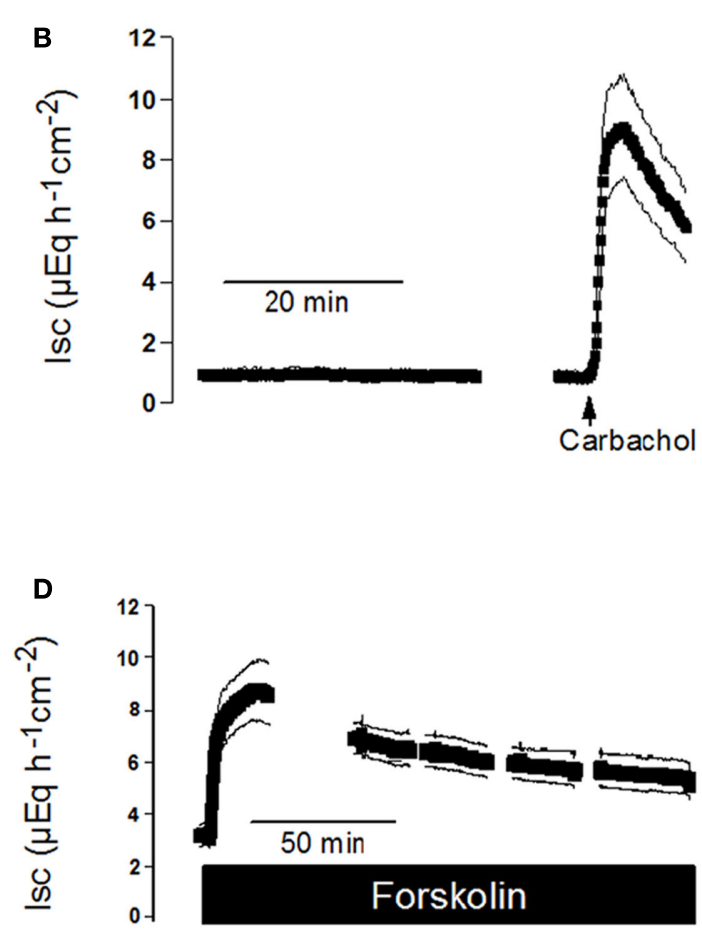

when administered at the mucosal side in order to block apical $\mathrm{K}^{+}$ channels mediating apical efflux of $\mathrm{K}^{+}$during potassium secretion, had any effect on the decrease in Isc induced by free cysteine suggesting that an induction of $\mathrm{K}^{+}$secretion is not involved in the effect of cysteine (Table 4).

In contrast, two of these $\mathrm{K}^{+}$channel blockers, i.e., $\mathrm{Ba}^{2+}$ and tetrapentylammonium, when administered at the serosal side in order to block basolateral $\mathrm{K}^{+}$channels, reversibly inhibited the Isc response evoked by free cysteine (Table 4). This observation would fit to a mechanism, in which free cysteine reduces basolateral $\mathrm{K}^{+}$ conductance. This $\mathrm{K}^{+}$conductance, which is dependent on the number of $\mathrm{K}^{+}$channels, their single channel conductance and their open probability, keeps the membrane potential at hyperpolarized values. If the $\mathrm{K}^{+}$channels involved are already inhibited by one of the $\mathrm{K}^{+}$channel blockers, this action of cysteine is no more possible. In the case of free cysteine, the observed cytosolic acidification (Figure 3A) might - at first glance - offer a reasonable explanation for the inhibition of basal $\mathrm{Cl}^{-}$secretion by free cysteine, as epithelial $\mathrm{K}^{+}$conductance is known to be sensitive to a fall in cytosolic pH (Diener and Scharrer, 1994). Any inhibition of $\mathrm{K}^{+}$conductance, will reduce the driving force for $\mathrm{Cl}^{-}$exit across the apical membrane via apical anion channels and thereby lead to an inhibition of transepithelial anion secretion.

This acidification and the presumed inhibition of cellular $\mathrm{K}^{+}$ conductance is probably the reason why the second, prosecretory serosal side; arrows) caused transient reductions in the Isc evoked by forskolin $\left(5 \times 10^{-6} \mathrm{~mol} \cdot \mathrm{I}^{-1}\right.$ at the mucosal and the serosal side; black bar) compared to a time-dependent control not treated with $\mathrm{Na}$ cysteinate (D). Line interruptions are caused by omission of time intervals of 5-10 min in order to synchronize the tracings of individual records to the administration of drugs. Values are means (symbols) \pm SEM (lines), $n=6$. For statistics, see text. response evoked by the $\mathrm{pH}$-neutral form of the amino acid, $\mathrm{Na}$ cysteinate, is missing in the case of free cysteine. Nevertheless, a fall in $\mathrm{pH}$ cannot be the reason for the initial inhibition in basal anion secretion evoked by Na cysteinate (see fall in Isc, e.g., in Figure 1B), as $\mathrm{Na}$ cysteinate does not affect cytosolic $\mathrm{pH}$ in the epithelial cells (Figure 3B). As this fall in Isc as well as the increase in Isc evoked by $\mathrm{Na}$ cysteinate was sensitive to inhibition of $\mathrm{H}_{2} \mathrm{~S}$-synthesizing enzymes (see Results), these results suggest that the functional response induced by this gasotransmitter depends on the velocity of the $\mathrm{H}_{2} \mathrm{~S}$ release and/or the local concentration reached. This is supported by the comparison with compounds known to release $\mathrm{H}_{2} \mathrm{~S}$ at different velocity. Whereas the very slowly releasing compound GYY 4137 never induced an increase in Isc, but only evoked a prolonged fall in baseline Isc (Figure 4A), diallyl trisulfide only increased Isc, and the rapidly releasing molecule NaHS polyphasically changed the current across the colonic epithelium (Figure 4B). Consequently, the local concentration of $\mathrm{H}_{2} \mathrm{~S}$ seems to critically determine whether this gasotransmitter exerts a prosecretory or an antisecretory action in the gastrointestinal mucosa.

\section{ACKNOWLEDGMENTS}

The diligent care of Mrs. B. Brück, E. Haas, B. Schmitt, and A. Stockinger is a pleasure to acknowledge. Supported by Deutsche Forschungsgemeinschaft, grant Di 388/11-1. 


\section{REFERENCES}

Berkefeld, H., Fakler, B., and Schulte, U. (2010). $\mathrm{Ca}^{2+}$-activated $\mathrm{K}^{+}$ channels: From protein complexes to function. Physiol. Rev. 90, 1437-1459.

Binder, H. J., and Sandle, G. J. (1994). "Electrolyte transport in the mammalian colon," in Physiology of the Gastrointestinal Tract, 3rd Edn, ed. L. R. Johnson (New York: Raven Press), 2133-2171.

Böhme, M., Diener, M., and Rummel, W. (1991). Calcium- and cyclicAMP-mediated secretory responses in isolated colonic crypts. Pflügers Arch. 419, 144-151.

Chávez-Piña, A. E., Tapia-Alvarez, G. R., and Navarrete, A. (2010). Inhibition of endogenous hydrogen sulfide synthesis by PAG protects against ethanol-induced gastric damage in the rat. Eur. J. Pharmacol. 630, 131-136.

Cook, N. S., and Quast, U. (1990). "Potassium channels. Structure, classification, function and therapeutic potential," in Potassium Channel Pharmacology, ed. N. S. Cook (New York: Ellis Horwood), 181-255.

Diener, M., and Scharrer, E. (1994). The effect of short-chain fatty acids on $\mathrm{Cl}-$ and $\mathrm{K}^{+}$conductance in rat colonic crypts. Pflügers Arch. 426, 472-480.

Ekundi-Valentim, E., Santos, K. T., Camargo, E. A., Denadai-Souza, A., Teixeira, S. A., Zanoni, C. I., Grant, A. D., Wallace, J. L., Muscará, M. N., and Costa, S. K. (2010). Differing effects of exogenous and endogenous hydrogen sulphide in carrageenan-induced knee joint synovitis in the rat. Br. J. Pharmacol. 159, 1463-1474.

Fiorucci, S., Orlandi, S., Mencarelli, A., Caliendo, G., Santagada, V., Distrutti, E., Santucci, L., Cirino, G., and Wallace, J. L. (2007). Enhanced activity of a hydrogen sulphide-releasing derivative of mesalamine (ATB-429) in a mouse model of colitis. Br. J. Pharmacol. 150, 996-1002.

Hennig, B., and Diener, M. (2009). Actions of hydrogen sulfide on ion transport across rat distal colon. $\mathrm{Br}$. J. Pharmacol. 158, 1263-1275.

Hörger, S., Schultheiss, G., and Diener, M. (1998). Segment-specific effects of epinephrine on ion transport in the colon of the rat. Am. J. Physiol. Gastrointest. Liver Physiol. 275, G1367-G1376.

Ji, Y., Pang, Q. F., Xu, G., Wang, L., Wang, J. K., and Zeng, Y. M. (2008). Exogenous hydrogen sulfide postconditioning protects isolated rat hearts against ischemia-reperfusion injury. Eur. J. Pharmacol. 587, 1-7.

Jimenez, M. (2010). Hydrogen sulfide as a signaling molecule in the enteric nervous system. Neurogastroenterol. Motil. 22, 1149-1153.

Kaplan, M. R., Mount, D. B., Delpire, E., Gamba, G., and Hebert, S. C. (1996). Molecular mechanisms of $\mathrm{NaCl}$ cotransport. Annu. Rev. Physiol. 58, 649-668.

Krueger, D., Foerster, M., Mueller, K., Zeller, F., Slotta-Huspenina, J., Donovan, J., Grundy, D., and Schemann, M. (2010). Signaling mechanisms involved in the intestinal prosecretory actions of hydrogen sulfide. Neurogastroenterol. Motil. 22, 1224-1231.

Lee, S. W., Hu, Y. S., Hu, L. F., Lu, Q., Dawe, G. S., Moore, P. K., Wong, P. T., and Bian, J. S. (2006). Hydrogen sulphide regulates calcium homeostasis in microglial cells. Glia 54, 116-124.

Lindström, C. G., Rosengren, J. E., and Fork, F. T. (1979). Colon of the rat. An anatomic, histologic and radiographic investigation. Acta Radiol. Diagn. (Stockh.) 20, 523-536.

Maguire, D., MacNamara, B., Cuffe, J. E., Winter, D., Doolan, C. M., Urbach, V., O'Sullivan, G. C., and Harvey, B. J. (1999). Rapid responses to aldosterone in human distal colon. Steroids 64, 51-63.

Martelli, A., Testai, L., Breschi, M. C., Blandizzi, C., Virdis, A., Taddei, S., and Calderone, V. (2011). Hydrogen sulphide: novel opportunity for drug discovery. Med. Res. Rev. 31, doi: $10.1002 / \operatorname{med} 20234$

Martin, G. R., McKnight, G. W., Dicay, M. S., Coffin, C. S., Ferraz, J. G. P., and Wallace, J. L. (2010). Hydrogen sulphide synthesis in the rat and mouse gastrointestinal tract. Dig. Liver Dis. 42, 103-109.

Park, K. J., Baker, S. A., Cho, S. Y., Sanders, K. M., and Koh, S. D. (2005). Sulfur-containing amino acids block stretch-dependent $\mathrm{K}^{+}$ channels and nitrergic responses in the murine colon. Br. J. Pharmacol. 144, 1126-11387.

Pfeffer, M., and Ressler, C. (1967). $\beta$ Cyanoalanine, an inhibitor of rat liver cystathionase. Biochem. Pharmacol. 16, 2299-2308.

Pouokam, E., and Diener, M. (2011) Mechanims of actions of hydrogen sulfide at rat distal colonic epithelium. Br. J. Pharmacol. 162, 392-404.

Rink, T. J., Tsien, R., and Pozzan, T. (1982). Cytoplasmic $\mathrm{pH}$ and free $\mathrm{Mg}^{+}$in lymphocytes. J. Cell Biol. 95, 189-196.

Schicho, R., Krueger, D., Zeller, F., von Weyhern, C. W. H., Frieling, T., Kimura, H., Ishii, I., De Giorgio, R., Campi, B., and Schemann, M. (2006). Hydrogen sulfide is a novel prosecretory neuromodulator in the guinea-pig and human colon. Gas troenterology 131, 1542-1552.

Schirgi-Degen, A., and Beubler, E. (1995). Significance of nitric oxide in the stimulation of intestinal fluid absorption in the rat jejunum in vivo. Br. J. Pharmacol. 114, 13-18.

Schultheiss, G., Seip, G., Kocks, S. L., and Diener, M. (2002). Ca2 ${ }^{+}$-dependent and $\mathrm{Ca}_{2}{ }^{+}$-independent $\mathrm{Cl}$ - secretion stimulated by the nitric oxide donor, GEA 3162, in rat colonic epithelium. Eur. J. Pharmacol. 444, 21-30.

Seamon, K. B., and Daly, J. W. (1981). Forskolin: a unique diterpene activator of cyclic AMP-generating systems. J. Cyclic Nucleotide Res. 7, 201-224.

SØrensen, M. V., Matos, J. E., Praetorius, H. A., and Leipziger, J. (2010). Colonic potassium handling. Pflügers Arch. 459, 645-656.

Steidle, J., and Diener, M. (2011). Effects of carbon monoxide on ion transport across rat distal colon. Am. J. Physiol. Gastrointest. Liver Physiol. 300, G207-G216.

Strabel, D., and Diener, M. (1995). Evidence against direct activation of chloride secretion by carbachol in the rat distal colon. Eur. J. Pharmacol. 274, 181-191.

Tamizhselvi, R., Moore, P. K., and Bhatia, M. (2007). Hydrogen sulfide acts as a mediator of inflammation in acute pancreatitis: in vitro studies using isolated mouse pancreatic acinar cells. J. Cell. Mol. Med. 11 315-326.
Toda, N., and Herman, A. G. (2005). Gastrointestinal function regulation by nitrergic efferent nerves. Pharmacol. Rev. 57, 315-338.

Van den Brandhof, W. E., Haks, K., Schouten, E. G., and Verhoef, P. (2001). The relation between plasma cysteine, plasma homocysteine and coronary atherosclerosis. Atherosclerosis 157, 403-409.

Wallace, J. L., Caliendo, G., Santagada, V., and Cirino, G. (2010). Markedly reduced toxicity of a hydrogen sulphide-releasing derivative of naproxen (ATB-346). Br. J. Pharmacol. 159, 1236-1246.

Wallace, J. L., Vong, L., McKnight, W., Dicay, M., and Martin, G. R. (2009). Endogenous and exogenous hydrogen sulfide promotes resolution of colitis in rats. Gastroenterology 137, 569-578.

Wang, R. (2002). Two's company, three's a crowd: can $\mathrm{H} 2 \mathrm{~S}$ be the third endogenous gaseous transmitter? FASEB J. 16, 1792-1798.

Zhao, W., Ndisang, J. S., and Wang, R. (2003). Modulation of endogenous production of $\mathrm{H} 2 \mathrm{~S}$ in rat tissues. Can. J. Physiol. Pharmacol. 81, 848-853.

Conflict of Interest Statement: The authors declare that the research was conducted in the absence of any commercial or financial relationships that could be construed as a potential conflict of interest.

Received: 25 January 2012; paper pending published: 07 February 2012; accepted: 17 February 2012; published online: 02 March 2012.

Citation: Pouokam $E$ and Diener $M$ (2012) Modulation of ion transport across rat distal colon by cysteine. Front. Physio. 3:43. doi: 10.3389/fphys.2012.00043

This article was submitted to Frontiers in Membrane Physiology and Biophysics, a specialty of Frontiers in Physiology. Copyright (C) 2012 Pouokam and Diener. This is an open-access article distributed under the terms of the Creative Commons Attribution Non Commercial License, which permits non-commercial use, distribution, and reproduction in other forums, provided the original authors and source are credited. 